\title{
Expression of mRNA for human type-I LHRH receptor transcript forms in human benign prostatic hyperplasia
}

\author{
BERNADETT RÓZSA ${ }^{1}$, ALIZ JUHÁSZ ${ }^{1}$, ANDREA TRESZL ${ }^{1}$, GYÖRGY TÓTH$^{2}$, TIBOR FLASKÓ ${ }^{2}$, \\ BALÁZS DEZSÖ ${ }^{3}$, NORMAN L. BLOCK ${ }^{4}$, ANDREW V. SCHALLY ${ }^{4,5}$ and GÁBOR HALMOS ${ }^{1,4}$ \\ ${ }^{1}$ Department of Biopharmacy, School of Pharmacy, Departments of ${ }^{2}$ Urology and ${ }^{3}$ Pathology, School of Mecicine, \\ Medical and Health Science Center, University of Debrecen, 4032 Debrecen, Hungary; ${ }^{4}$ Department of Pathology, \\ Miller School of Medicine, University of Miami, Miami, FL 33101; ${ }^{5}$ Endocrine, Polypeptide and Cancer Institute, \\ Veterans Affairs Medical Center and South Florida Veterans Affairs Foundation for Research and Education, \\ Miami, FL 33125, and the Department of Pathology and Department of Medicine, Division of \\ Hematology-Oncology, Miller School of Medicine, University of Miami, Miami, FL 33101, USA
}

Received April 21, 2009; Accepted June 19, 2009

DOI: 10.3892/ijo_00000420

\begin{abstract}
The presence of four different isoforms of luteinizing hormone-releasing hormones (LHRH) and one LHRH receptor (LHRH-R) has been reported in vertebrates. In the human genome only LHRH-I and LHRH-II genes have been identified. The human LHRH-I gene is composed of four exons separated by three introns. Three LHRH receptor or receptor-like genes have been demonstrated. The wellestablished type-I LHRH receptor (LHRH-R-I) gene is composed of three exons separated by two introns. In this study we investigated the expression of transcript forms of LHRH-R-I in human benign prostatic hyperplasia (BPH) with reverse transcriptase-polymerase chain reaction (RT-PCR) using gene specific primers. Thirty-five human BPH specimens were obtained at surgery. Normal human pituitaries collected at autopsy served as control. RNA extraction and RT-PCR with gene-specific primers for LHRH-R-I forward (F1)/reverse (R1), LHRH-R-I F2/R3, LHRH-R-I F1'/R2' were carried out to determine the mRNA expression for LHRH-R-I transcript forms. The expected PCR products amplified with gene specific primers were LHRH-R-I F1/R1 with 319 bp, LHRHR-I F2/R3 with 309 bp and LHRH-R-I F1'/R2' with 219 bp. PCR products for LHRH-R-I F1/R1 were detected in $21(60 \%)$ and for LHRH-R-I F2/R3 in 5 of 35 (14\%) BPH samples. No PCR products for LHRH-R-I F1'/R2' were found. In
\end{abstract}

Correspondence to: Dr Gabor Halmos, Department of Biopharmacy, School of Pharmacy, Medical and Health Science Center, University of Debrecen, Nagyerdei krt. 98, H-4032 Debrecen, Hungary

E-mail: halmos@king.pharmacol.dote.hu

Key words: receptors for LHRH, transcript forms, human benign prostatic hyperplasia conclusion, we detected mRNA for LHRH-R-I in human BPH specimens. Our results suggest that LHRH-R-I gene may have more than two splice variants or uncharacterised transcript forms of LHRH-R-I. Our findings support the merit of further investigation of the expression of LHRH-R-I and its transcript forms in human $\mathrm{BPH}$.

\section{Introduction}

Luteinizing hormone-releasing hormone-I (LHRH-I), also known as gonadotropin hormone-releasing hormone, $(\mathrm{GnRH})$ is the primary link between the brain and the pituitary in the regulation of gonadal function and plays a pivotal role in vertebrate reproduction (1). The discovery of LHRH has had a major impact on medicine and has led to a variety of clinical uses of LHRH analogs in oncology and gynecology (1). Most vertebrates express at least two LHRH isoforms. In the human genome only LHRH-I (mammalian LHRH) and LHRH-II (chicken LHRH-II) genes were identified. LHRH-II has been likewise found in tumors such as breast carcinoma, but the functional receptor for LHRH-II is absent in humans (1). The human LHRH-I gene is composed of four exons separated by three introns and is present as a single gene copy on chromosome 8p11.2-p21 $(2,3)$. Three LHRH receptors or receptor-like genes were demonstrated earlier (2-6). The well-established type-I LHRH receptor (LHRH-R-I) gene has been identified as a single copy on chromosome $4 q 21.2(4,5)$ and is composed of three exons separated by two introns (6). A vast literature indicates that the LHRH-I is expressed not only in the hypothalamus but also in peripherial tissues, both normal and tumoral (7-16). However, only limited findings are available on the presence of full length LHRH-R-I and its splice variants or transcript forms in human malignant and benign tissues $(17,18)$. The LHRH-R-I belongs to the $\mathrm{G}$ protein-coupled receptor (GPCRs) family $(19,20)$ with seven transmembrane domains (TMs) connected by extracellular loops (ECLs) and intracellular loops (ICLs). 
LHRH-R-I is expressed on the surface of pituitary gonadotrope cells $(1,19)$. This receptor is characterized by the unique absence amongst GPCRs of a carboxyl-terminal tail (21). LHRH-R-I has much higher affinity for LHRH-I than for LHRH-II (22-24). Based on their ligand binding proporties LHRH receptors appear to be quite similar in the human pituitary, human normal extrapituitary tissues and human cancers, but their signalling pathways are different $(25,26)$. In the past 25 years several thousand LHRH analogs have been synthesized. Many analogs were shown to have important clinical applications in gynecology, oncology and urology (1,9,27-29).

Only LHRH-R-I was isolated as a functional receptor in human tissues. Earlier, three different mRNA products for LHRH-R-I have been identified (30). Two splice variants of the LHRH-R-I (LHRH-R-I Sb1), termed Sb2 and Sb3 have been reported $(17,18)$. The shorter transcript $\mathrm{Sb} 3$ contains a 220-bp deletion in exon 2, the other splice variant Sb2 carries a shorter deletion of $128 \mathrm{bp}$. The expression of LHRH-R-I has been demonstrated in normal and malignant tissues by several groups, although some investigators did not use primers designed for the full length LHRH-R-I gene (31-33).

The aim of our work was to investigate the mRNA expression for LHRH-R-I transcript forms in human benign prostatic hyperplasia (BPH) specimens. Our study was carried out with previously published primers as well as with LHRH-R-I specific primers designed by us. LHRH-I receptor transcripts have been already extensively studied in various human tissues, including those of the breast, endometrium, prostate and ovary. In our work, we investigated the mRNA expression for LHRH-R-I transcript forms in human BPH specimens using RT-PCR.

\section{Materials and methods}

Tissue samples. Human BPH specimens from 35 patients (mean age, 67.9 years; range, 55-82 years) were collected at the Department of Urology, University of Debrecen, Debrecen, Hungary. Approximately $8-10 \mathrm{~mm}^{3}$ of each tissue was used for molecular biology studies. Histopathological examinations of each specimen was undertaken to confirm the presence of benign prostatic hyperplasia (BPH) before the molecular biology studies. Two normal pituitary samples were collected at autopsy from the Department of Pathology, University of Debrecen and were used as positive controls. After removal, all samples were flash frozen and stored at $-70^{\circ} \mathrm{C}$. The collection of human tissue specimens and the experimental protocol have been approved by the Institutional Ethics Committee for the current study and the patients gave informed consent.

RNA isolation and RT-PCR. Tissues were homogenized with a Mikro-Dismembrator-U (Sartorius B.Braun Biotech, Melsunge, Germany) and RNA was extracted with Nucleospin Total RNA Isolation Kit (Macherey-Nagel, Germany). RNA concentration and purity were determined using the Nanodrop ND-1000 UV Spectrophotometer (Nanodrop Technologies, Wilmington, DE, USA). Total RNA (100-250 ng) was reverse transcribed to cDNA with MMLV Reverse Transcriptase (Promega Co., Madison, WI, USA) according to the manu-

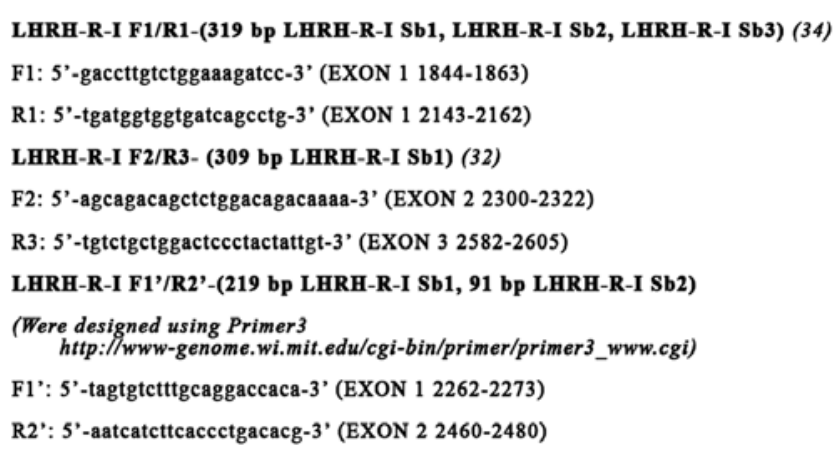

Figure 1. Nomenclature, sequence and position of forward $(F)$ and reverse $(R)$ oligonucleotide primers with reference to human LHRH-R-I cDNA sequence published previously $(19,20)$.

facturer's instructions. For amplification from first strand cDNA gene-specific primers for LHRH-R-I (forward) F1/ (reverse) R1: F1:5'-GACCTTGTCTGGAAAGATCC-3' (exon 1 1844-1863) and R1: 5'-TGATGGTGGTGATCAGC CTG-3' (exon 1 2143-2162), LHRH-R-I F2/R3: F2: 5'-AGC AGACAGCTCTGGACAGACAAAA-3' (exon 2 2300-2322) and R3: 5'-TGTCTGCTGGACTCCCTACTATGT-3' (exon 3 2582-2605), and beta actin (bACT) housekeeping gene F3/R4: F3: 5'-GGCATCCTCACCCTGAAGTA-3' (exon 3) R4: 5'-GGGGTGTTGAAGGTCTCAAA-3' (exon 4) were described earlier $(32,34-36)$ (Fig. 1). Primers for LHRH-R-I F1'/R2': F1': 5'-TAGTGTCTTTGCAGGACCACA-3' (exon 1 2262-2273) and R2': 5'-AATCATCTTCACCCTGACACG-3' (exon 2 2460-2480) were designed using Primer3 (http://wwwgenome.wi.mit.edu/cgi-bin/primer/primer3_www.cgi). For LHRH-R-I F1/R1, LHRH-R-I F1'/R2' and bACT, the PCR reaction mixture contained $2 \mu \mathrm{ldDNA}, 1.5 \mathrm{mM} \mathrm{MgCl} 2,0.5 \mu \mathrm{M}$ of each primer (Invitrogen), 1X PCR buffer, $200 \mu \mathrm{M}$ of each $\mathrm{dNTP}$, and $1 \mathrm{U}$ Taq Polymerase (Invitrogen) in a final volume of $25 \mu \mathrm{l}$. After denaturation $\left(3 \mathrm{~min}\right.$ at $\left.94^{\circ} \mathrm{C}\right) \mathrm{cDNA}$ was amplified for 45 cycles $\left(45 \mathrm{sec}\right.$ at $94^{\circ} \mathrm{C}$; $30 \mathrm{sec}$ at $60^{\circ} \mathrm{C}$; and $90 \mathrm{sec}$ at $72^{\circ} \mathrm{C}$ ), bACT was amplified with 30 cycles, then a final elongation step at $72^{\circ} \mathrm{C}$ for 10 min was applied.

For LHRH-R-I F2/R3 the PCR reaction mixture contained $2 \mu \mathrm{cDNA}, 3 \mathrm{mM} \mathrm{MgCl}{ }_{2}, 0.5 \mu \mathrm{M}$ of each primer (Invitrogen), 1X PCR buffer, $200 \mu \mathrm{M}$ of each dNTP, and $1 \mathrm{U}$ Taq Polymerase (Invitrogen) in a final volume of $25 \mu 1$. After denaturation $\left(3 \mathrm{~min}\right.$ at $94^{\circ} \mathrm{C}$ ) cDNA was amplified for 45 cycles (45 sec at $94^{\circ} \mathrm{C} ; 30 \mathrm{sec}$ at $66^{\circ} \mathrm{C}$; and $90 \mathrm{sec}$ at $72^{\circ} \mathrm{C}$ ) and then a final elongation step at $72^{\circ} \mathrm{C}$ for $10 \mathrm{~min}$ was applied. PCR products were separated electrophoretically on $1.5 \%$ agarose gel and stained with ethidium bromide.

\section{Results}

Expression of mRNA for human type-I LHRH receptors in human benign prostatic hyperplasia. RT-PCR analysis was carried out to investigate the expression of different LHRH-R transcript forms in human BPH tissue samples. We used LHRH-R-I F1/R1 primers encompassing the open reading frame (ORF) from exon 1 to exon 1, LHRH-R-I F2/R3 from exon 2 to exon 3 and LHRH-R-I F1'/R2' primers from exon 1 


\begin{tabular}{|c|c|c|}
\hline Gene & GNRHR & Variant 1 \\
\hline DNA: & $15.61 \mathrm{~Kb}$ & NT 022778 \\
\hline mRNA: & 2738 bp & NM 000406 \\
\hline CDS: & 987 bp & NP 000397 \\
\hline
\end{tabular}

\section{NM_000406}

1741 cctgggaaa tatggcaaac agtgectctc ctgaacagaa tcaaatcac tgttcagcca 1801 tcaacaacag catcccactg atgcagggca acctccccac tctgaccttg tctggaaga 1861 tecgagtgac ggttactte ttecttetc tgetetetge gacettaat gettettet 1921 tgttgaaact tcagaagtgg acacagaaga aagagaaagg gaaaagctc tcaagaatga 1981 agctgctctt aaacatctg accttagcca acctgttgga gactctgatt gtcatgccac 2041 tggatgggat gtggaacatt acagtccaat ggtatgetgg agagttactc tgcaaagttc 2101 teagttatet aagettte tecatgtatg ceceagect catgatggtg gtgateagec 2161 tggaccgctc cetggctatc acgaggcccc tagctttgaa aagcaacagc aaagtcggac 2221 agtccatggt tggectggce tggatcctca gtagtgtctt tgcaggacca cagttataca 2221 agtccatggt tggcetggec tggatcetca gtagtgtcte tgcaggacca cagttataca 2281 tcttcagat gattcatcta gcagacagct ctggacagac aaaagttttc tetcaatgt ttcaccttca 2401 gctgcetct catcatccet ctttcatca tgctgatctg caatgcaaa atcatcttce 2471 ccetgacacg ggtcettcat caggaccecc acgaactaca actgaatcag tccaagaaca 2521 atataccaag agcacggetg aagactctaa aaatgacggt tgcatttgcc acttcattta 2581 ctgtetgetg gactecetac tatgtectag gaattggta ttggtttgat cetgaaatgt 2641 taaacaggtt gtcagaccea gtaaatcact tcttctttct ctttgccttt ttaaaccat 2701 gcttgatcc acttatctat ggatattte ctctgtga

Figure 2. Coding nucleotide sequence (CDS:1752-2738) of the human LHRH-R-I gene. The start and the stop codons are marked with red lowercase letters. Gene specific primers for LHRH-R-I F1/R1, LHRH-R-I F2/R3 and LHRH-R-I F1'/R2' are marked with blue, green and yellow, respectively. The nucleotide sequences of the human type-I LHRH receptor (19) were used to query the human genome sequence using the BLAST search programs of the National Center for Biotechnology Information (NCBI) (http://www.ncbi.nlm.nih.gov/blast/Blast.cgi)

to exon 2 (Figs. 1 and 2). The predicted size of the PCRamplified LHRH-R F1/R1 cDNA was 319 bp for the full- length transcript (sb1), for the partial exon 2-deleted variant (sb2) and for the exon 2-lacking (sb3). The predicted size of the PCR-amplified LHRH-R F2/R3 cDNA was 309 bp for the full-length transcript (sb1). The predicted size of the PCR-amplified LHRH-R F1'/R2' cDNA was 219 bp for the full-length transcript (sb1) and $91 \mathrm{bp}$ for the partial exon 2deleted variant (sb2) (Fig. 3). PCR products for LHRH-R-I F1/R1 were detected in 21 of $35(60 \%)$ human BPH specimens. PCR products for LHRH-R-I F2/R3 were detected in 5 of $35(14 \%) \mathrm{BPH}$ specimens. We were not able to demonstrate PCR products for LHRH-R-I F1'/R2' in any of the BPH samples investigated (Tables I and II). Although LHRH-R-I transcripts have been previously detected in extensive series of human tissues (18), in our study we were not able to find the mRNA for the full length LHRH-R-I by RT-PCR. PCR amplification with human bACT genespecific primers generated a single product of the expected size of $203 \mathrm{bp}$ in all samples investigated.

Expression of mRNA for human type-I LHRH receptors in human pituitary tissue. In human pituitary tissue samples, used as a positive control, we were able to detect the mRNA for LHRH-R-I transcript forms with all the three primer sets applied in our study (Fig. 3). We could not detect the partial exon 2-deleted variant (sb2) using LHRHR-I F1'/R2' primers in the human pituitary samples investigated. We did not use specific primers to detect the LHRH-R-I Sb3 that is also a variant lacking exon 2.
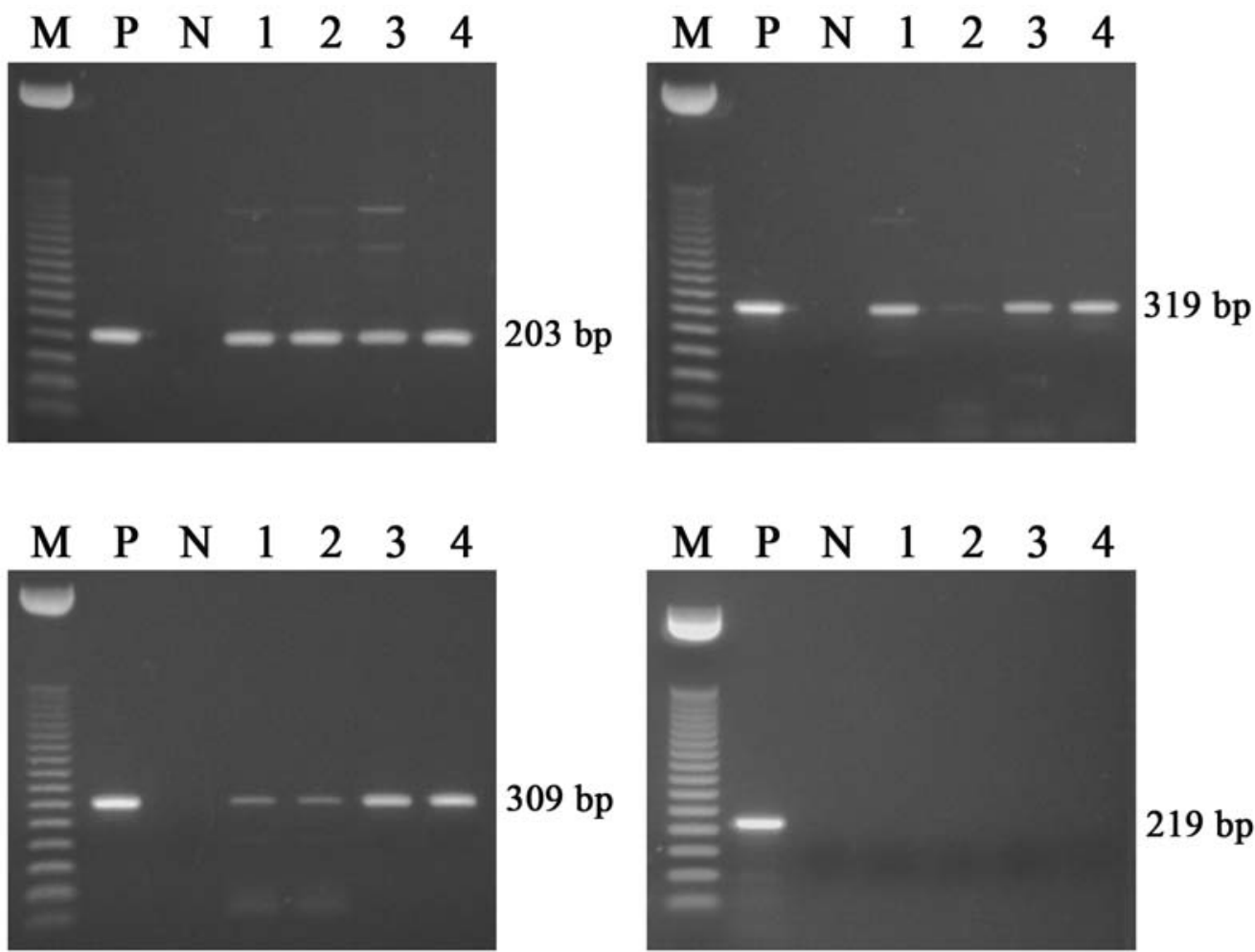

$219 \mathrm{bp}$

Figure 3. Representative RT-PCR analysis of mRNA for bACT (panel 1), LHRH-R-I F1/R1 (panel 2), LHRH-R-I F2/R3 (panel 3), LHRH-R-I F1'/R2' (panel 4) in human BPH specimens and in a human pituitary sample used as positive control. PCR products were separated electrophoretically on $1.5 \%$ agarose gel and stained with ethidium bromide. Lane M, molecular DNA marker (50 bp); lanes 1-4, BPH samples; lane N, no template control; lane P, positive control (human pituitary tissue). 
Table I. Clinicopathological findings and mRNA expression pattern of LHRH-R-I F1/R1, LHRH-R-I F2/R3 and LHRH-R-I F1'/R2' in human benign prostatic hyperplasia specimens.

Patient no. Patient age (years) $\quad$ PSA-value (ng/ml) $\quad$ bACT $\quad$ LHRH-R-I F1/R1 LHRH-R-I F2/R3 LHRH-R-I F1'/R2'

\begin{tabular}{|c|c|c|c|c|c|c|}
\hline 1. & 81 & - & + & + & + & - \\
\hline 2. & 55 & 0.45 & + & + & - & - \\
\hline 3. & 82 & Normal & + & + & - & - \\
\hline 4. & 70 & 3.52 & + & + & + & - \\
\hline 5. & 71 & 6.62 & + & + & - & - \\
\hline 6. & 65 & Increased & + & + & + & - \\
\hline 7. & 73 & 9.45 & + & + & - & - \\
\hline 8. & 66 & NA & + & + & - & - \\
\hline 9. & 62 & NA & + & + & - & - \\
\hline 10. & 70 & 1.12 & + & + & - & - \\
\hline 11. & 65 & NA & + & + & - & - \\
\hline 12. & 70 & 0.5 & + & + & - & - \\
\hline 13. & 56 & $10-12$ & + & + & - & - \\
\hline 14. & 64 & 2.4 & + & + & - & - \\
\hline 15. & 73 & 1.56 & + & + & - & - \\
\hline 16. & 76 & Normal & + & + & - & - \\
\hline 17. & 77 & 0.92 & + & + & - & - \\
\hline 18. & 55 & NA & + & - & - & - \\
\hline 19. & 67 & 3.21 & + & - & - & - \\
\hline 20. & 59 & NA & + & - & - & - \\
\hline 21. & 74 & NA & + & - & - & - \\
\hline 22. & 61 & NA & + & - & - & - \\
\hline 23. & 75 & 1.57 & + & + & - & - \\
\hline 24. & 74 & 3.76 & + & + & - & - \\
\hline 25. & 75 & 10.84 & + & - & - & - \\
\hline 26. & 73 & NA & + & + & - & - \\
\hline 27. & 68 & 3.84 & + & - & - & - \\
\hline 28. & 67 & NA & + & - & - & - \\
\hline 29. & 69 & NA & + & - & + & - \\
\hline 30. & 75 & NA & + & - & + & - \\
\hline 31. & 62 & NA & + & + & - & - \\
\hline 32. & 67 & 0.3 & + & - & - & - \\
\hline 33. & 58 & NA & + & - & - & - \\
\hline 34. & 76 & 2.26 & + & - & - & - \\
\hline 35. & 55 & NA & + & - & - & - \\
\hline
\end{tabular}

NA, not available.

Table II. Expression of mRNA for the bACT, LHRH-R-I F1/R1, LHRH-R-I F2/R3, and LHRH-R-I F1'/R2' in human benign prostatic hyperplasia samples.

\begin{tabular}{lcc}
\hline Gene & $\begin{array}{c}\text { Positive/total } \\
\text { sample size }\end{array}$ & $\%$ Positive \\
\hline bACT & $35 / 35$ & 100 \\
LHRH-R-I F1/R1 & $21 / 35$ & 60 \\
LHRH-R-I F2/R3 & $5 / 35$ & 14 \\
LHRH-R-I F1'/R2' & $0 / 35$ & 0 \\
\hline
\end{tabular}

\section{Discussion}

LHRH agonists have been used extensively for the treatment of various diseases and medical conditions, in which the suppression of gonadotropin and/or gonadal steroid hormone secretion is desired. The possible usefulness of LHRH analogs in treatment of human benign prostatic hyperplasia based in part on direct effects is also suggested by numerous reports $(1,9)$. Experimental and clinical evidence indicates the existence of a functional LHRH loop, and the presence of specific LHRH receptors in human BPH $(1,9,34)$. In the present study, we examined the expression of LHRH-R-I 
gene in 35 human BPH specimens. Our work represents the first demonstration of the presence of LHRH-R-I transcripts in human BPH tissue samples obtained after radical prostatectomy. We were able to detect that the transcripts of LHRH-R-I were widely distributed in human BPH samples. In our study, sequences of LHRH-R-I from exon 1 to exon 1 were amplified in $60 \%$ of the specimens and sequences from exon 2 to exon 3 were detected in $14 \%$ of the human BPH tissue samples investigated. However, we could not find sequences from exon 1 to exon 2 that correspond to the full-length LHRH-R-I sequences. Our results could be explained by the fact that LHRH-R-I gene may have more than two splice variants or other, uncharacterised transcript forms. We also confirmed the expression of the LHRH-R-I gene transcripts in human pituitary samples. By alternative splicing, multiple transcripts can be generated from a single gene. This represents an important/key molecular mechanism of gene regulation in physiological and pathophysiological processes. It is important to note that different transcript forms of mRNA for LHRH-R-I were expressed in human $\mathrm{BPH}$ specimens, but these transcripts are not the same variants lacking exon 2. Finch et al (37) suggests that LHRH-R-I splicing may be regulated in a tissue-specific manner, or under specific hormonal or metabolic conditions. Generation of protein isoforms by alternative splicing is known to occur in numerous members of the G-protein-coupled receptors family (38-40), correlating with differences in affinity, potency, coupling efficiency, specificity and sensitivity to desensitization of the receptors. Differential splicing could also have a physiological significance, as production of a short transcript was shown to downregulate the level of a wild-type (WT) transcript (41). Splice variants of peptide hormone receptors can differ fundamentally from their WT receptor counterparts in pharmacological and functional characteristics, in their distribution in normal and malignant human tissues, and in their potential use for clinical applications. It is wellestablished that regulation of splicing may provide another control mechanism in the expression of the LHRH-R-I gene in the human pituitary and extrapituitary tissues. Although LHRH-I receptor transcripts were detected in an extensive series of human tissues, including those of the breast, uterus, endometrium, prostate and ovary (42-52), we have been unable, so far, to find full length LHRH-R-I using RT-PCR analyses. Although pituitary and extrapituitary LHRH-R-I transcripts appear identical, their functional characteristics may differ. In the pituitary, LHRH-R-I are coupled via $\mathrm{G}_{\mathrm{q} / 11}$ to phospho-lipase $\mathrm{C}$ (PLC), causing an $\mathrm{IP}_{3}$-mediated mobilization of $\mathrm{Ca}^{2+}$ and a protein kinase $\mathrm{C}$-mediated activation of MAP kinases. However, there is little evidence for PLC activation by endogenous extrapituitary LHRH-R-I $(44,48)$. Instead, $\mathrm{G}_{\mathrm{i}}$-mediated activation of protein phosphatase and inhibition of MAP kinase activity may be the basis of some of the antiproliferative effects mediated by LHRH-R-I $(44,46,52,53)$. Investigation of the expression of extrapituitary LHRH-R-I revealed major functional differences between LHRH-R-I in human pituitary and extrapituitary sites, in spite of the expression of identical receptor transcripts (19). In radioligand binding studies (26), pituitary LHRH-R-I displayed high affinity for agonists such as buserelin [dissociation constant $\left(\mathrm{K}_{\mathrm{d}}\right)$ values being in the $\mathrm{nM}$ range], whereas some extrapituitary tissues showed lower affinity $\left(\mathrm{K}_{\mathrm{d}}\right.$ values being in the $\mu \mathrm{M}$ range). In other reports, it was speculated that LHRH-R-I activation inhibits proliferation (or causes cell death) and the identical effects of agonists and antagonists would apply. Such agonist/antagonist dichotomy can be defined mainly with pituitary LHRH-R-I, but not with receptors expressed in extrapituitary sites $(26,47,48)$. The low proportion, conformation and the numbers/levels of LHRH-R-I in cell membranes could be important parameters for better understanding of the pathophysiological function of LHRH-R-I in extrapituitary sites (37). Although we failed to detect the full length LHRH-R-I in human BPH tissues, Kottler et al (18) demonstrated the presence of different LHRH-R-I transcripts in a variable percentage of human tumors and non-tumor tissues. The high incidence of specific, high affinity receptors for LHRH and the full-length LHRH-R-I mRNA in human prostate cancers and benign prostatic tissues was also described earlier (34). At present it is not clear whether alternative splicing of LHRH-R-I transcripts could play a physiological role. Alternatively spliced receptor isoforms have been implicated in altered receptor functions. In the human pituitary and extrapituitary tissues, including human $\mathrm{BPH}$, the regulation of splicing might provide another control mechanism in the expression of the LHRH-R-I gene.

Our findings support the merit of further investigation of the expression of LHRH-R-I and its transcript forms in human malignancies as well as the application of LHRH analogues for receptor-based diagnosis and treatment of human benign prostatic hyperplasia.

\section{Acknowledgments}

This work was supported in part by the L. Austin Week Family Endowment for Urologic Research and the Hungarian Health and Research Council ETT 240/2006 grant (G.H.).

\section{References}

1. Schally AV and Engel J: Drug insight: clinical use of agonists and antagonists of luteinizing hormone-releasing hormone. Nat Clin Pract Endocrinol Metab 3: 157-167, 2007.

2. Radovick S, Wondisford FE, Nakayama Y, Yamada M, Cutler GB and Weintraub BD: Isolation and characterization of the human gonadotropin-releasing hormone gene in the hypothalamus and placenta. Mol Endocrinol 4: 476-480, 1990.

3. Yang-Feng TL, Seeburg PH and Francke U: Human luteinizing hormone-releasing hormone gene (LHRH) is located on short arm of chromosome 8 (region8p11.2-p21). Somat Cell Mol Genet 12: 95-100, 1986.

4. Fan NC, Peng C, Krisinger J and Leung PC: The human gonadotropin-releasing hormone receptor gene: complete structure including multiple promoters, transcription initiation sites, and polyadenylation signals. Mol Cell Endocrinol 107: R1-R8, 1995.

5. Kakar SS: Molecular structure of the human gonadotropin releasing hormone receptor gene. Eur J Endocrinol 137: 183-192, 1997.

6. Leung PC, Squire J, Peng C, Fan N, Hayden MR and Olofsson JI: Mapping of the gonadotropin-releasing hormone $(\mathrm{GnRH})$ receptor gene to human chromosome $4 \mathrm{q} 21.2$ by fluorescence in situ hybridization. Mamm Genome 6: 309-310, 1995.

7. Chatzaki E, Bax CM, Eidne KA, Anderson L, Grudzinskas JG and Gallagher CJ: The expression of gonadotropin-releasing hormone hormone and its receptor in endometrial cancer, and its relevance as an autocrine growth factor. Cancer Res 56 : 2059-2065, 1996 
8. Chegini N, Rong H, Dou Q, Kipersztok S and Williams RS: Gonadotropin-releasing hormone $(\mathrm{GnRH})$ and $\mathrm{GnRH}$ receptor gene expression in human myometrium and leiomyomata and the direct action of GnRH analogs on myometrial smooth muscle cells and interaction with ovarian steroids in vitro. J Clin Endocrinol Metab 81: 3215-3221, 1996.

9. Schally AV, Halmos G, Rekasi Z and Arencibia JM: The action of LH-RH agonists, antagonists, and cytotoxic analogs on the LH-RH receptors on the pituitary and tumors. In: Infertility and Reproductive Medicine Clinics of North America. Vol. 12. Devroey P (ed.) pp17-44, 2001

10. Dong KW, Marcelin K, Hsu MI, Chiang CM, Hoffman G and Roberts JL: Expression of gonadotropin-releasing hormone $(\mathrm{GnRH})$ gene in human uterine endometrial tissue. Mol Hum Reprod 4: 893-898, 1998.

11. Raga F, Casan EM, Krussel JS, Wen Y, Huang HY, Nezhat C and Polan ML: Quantitative gonadotropin-releasing hormone gene expression and immunohistochemical localization in human endometrium throughout the menstrual cycle. Biol Reprod 59: 661-669, 1998

12. Harris N, Dutlow C, Eidne K, Dong KW, Roberts J and Millar R: Gonadotropin-releasing hormone gene expression in MDA-MB 231 and ZR-75-1 breast carcinoma cell lines. Cancer Res 51: 2577-2581, 1991.

13. Chen A, Kaganovsky E, Rahimipour S, Ben-Aroya N, Okon E and Koch Y: Two forms of gonadotropin-releasing hormone $(\mathrm{GnRH})$ are expressed in human breast tissue and overexpressed in breast cancer: a putative mechanism for the antiproliferative effect of GnRH by down-regulation of acidic ribosomal phosphoproteins P1 and P2. Cancer Res 62: 1036-1044, 2002.

14. Azad N, LaPaglia N, Kirsteins L, Uddin S, Steiner J, Williams DW, Lawrence AM and Emanuele NV: Jurkat cell proliferative activity is increased by luteinizing hormone releasing hormone. J Endocrinol 153: 241-249, 1997.

15. Choi KC, Auersperg N and Leung PC: Expression and antiproliferative effect of a second form of gonadotropin-releasing hormone in normal and neoplastic ovarian surface epithelial cells. J Clin Endocrinol Metab 86: 5075-5078, 2001.

16. Kang SK, Tai CJ, Nathwani PS and Leung PC: Differential regulation of two forms of gonadotropin-releasing hormone messenger ribonucleic acid in human granulosa-luteal cells. Endocrinology 142: 182-192, 2001

17. Grosse R, Schoneberg T, Schultz G and Gudermann T: Inhibition of gonadotropin-releasing hormone receptor signaling by expression of a splice variant of the human receptor. Mol Endocrinol 11: 1305-1318, 1997.

18. Kottler ML, Bergametti F, Carre MC, Morice S, Decoret E, Lagarde JP, Starzec A and Counis R: Tissue-specific pattern of variant transcripts of the human gonadotropin-releasing hormone receptor gene. Eur J Endocrinol 140: 561-569, 1999.

19. Stojilkovic SS, Reinhart J and Catt KJ: Gonadotropin releasing hormone receptors: structure and signal transduction pathways. Endocr Rev 15: 462-499, 1994.

20. Chi L, Zhou W, Prikhozhan A, Flanagan C, Davidson JS, Golembo M, Illing N, Millar RP and Sealfon SC: Cloning and characterization of the human GnRH receptor. Mol Cell Endocrinol 91: R1-R6, 1993.

21. Millar RP, Lu ZL, Pawson AJ, Flanagan CA, Morgan K and Maudsley SR: Gonadotropin-releasing hormone receptors. Endocr Rev 25: 235-275, 2004.

22. Millar RP, Zhu YF, Chen C and Struthers RS: Progress towards the development of non-peptide orally-active gonadotropinreleasing hormone $(\mathrm{GnRH})$ antagonists: therapeutic implications. Br Med Bull 56: 761-772, 2000.

23. Millar R, Lowe S, Conklin D, Pawson A, Maudsley S, Troskie B, Ott T, Millar M, Lincoln G, Sellar R, Faurholm B, Scobie G, Kuestner R, Terasawa E and Katz A: A novel mammalian receptor for the evolutionarily conserved type II GnRH. Proc Natl Acad Sci USA 98: 9636-9641, 2001.

24. Neill JD, Duck LW, Sellers JC and Musgrove LC: A gonadotropin-releasing hormone $(\mathrm{GnRH})$ receptor specific for $\mathrm{GnRH}$ II in primates. Biochem Biophys Res Commun 282: 10121018,2001

25. Emons G, Schröder B, Ortmann O, Westphalen S, Schulz KD and Schally AV: High affinity binding and direct antiproliferative effects of luteinizing hormone-releasing hormone analogs in human endometrial cancer cell lines. J Clin Endocrinol Metab 77: 1458-1464, 1993.
26. Emons G, Ortmann O, Becker M, Irmer G, Springer B, Laun R, Hölzel F, Schulz KD and Schally AV: High affinity binding and direct antiproliferative effects of LHRH analogues in human ovarian cancer cell lines. Cancer Res 53: 5439-5446, 1993.

27. Conn PM and Crowley WJ Jr: Gonadotropin-releasing hormone and its analogs. Annu Rev Med 45: 391-405, 1994.

28. Lippman ME: Endocrine-responsive cancer. In: Williams Textbook of Endocrinology. Wilson JD, Foster DW, Kronenberg HM and Larsen PR (eds.) W.B. Saunders Co., Philadelphia, PA, pp1675-1692, 1998.

29. Fauser BC, Devroey P, Yen SC, Gosden R, Crowley WF Jr, Baird DT and Bouchard P: Minimal ovarian stimulation for IVF: appraisal of potential benefits and drawbacks. Hum Reprod 14: 2681-2686, 1999

30. Kottler ML, Bergametti F, Carre' MC, Starzec A and Counis R: Alternative splicing and tissue distribution of transcripts for human gonadotropin-releasing hormone receptor. In: Program and Abstract of the 10th International Congress of Endocrinology, San Francisco, CA, 12-15 June 1996. Bethesda, MD, USA: Endocrine Society Press, pp3-252, 1996.

31. Straub B, Müller M, Krause H, Schrader M and Miller K: Real-time quantitative reverse transcriptase-polymerase chain reaction for luteinizing hormone-releasing hormone receptor gene mRNA expression in human prostate cancer. Urology 62: 172-176, 2003.

32. Wilson AC, Salamat MS, Haasl RJ, Roche KM, Karande A, Meethal SV, Terasawa E, Bowen RL and Atwood CS: Human neurons express type I GnRH receptor and respond to GnRH I by increasing luteinizing hormone expression. J Endocrinol 191: 651-663, 2006.

33. Imai A, Ohno T, Iida K, Fuseya $T$, Furui $T$ and Tamaya $T$ : Presence of gonadotropin-releasing hormone receptor and its messenger ribonucleic acid in endometrial carcinoma and endometrium. Gynecol Oncol 55: 144-148, 1994.

34. Halmos G, Arencibia JM, Schally AV, Davis R and Bostwick DG: High incidence of receptors for luteinizing hormone-releasing hormone (LHRH) and LHRH receptor gene expression in human prostate cancers. J Urol 163: 623-629, 2000.

35. Tang X, Yano T, Osuga Y, Matsumi H, Yano N, Xu J, Wada O, Koga K, Kugu K, Tsutsumi O, Schally AV and Taketani Y: Cellular mechanisms of growth inhibition of human epithelial ovarian cancer cell line by LH-releasing hormone antagonist Cetrorelix. J Clin Endocrinol Metab 87: 3721-3727, 2002.

36. Ovstebo R, Haug KB, Lande K and Kierulf P: PCR-based calibration curves for studies of quantitative gene expression in human monocytes: development and evaluation. Clin Chem 49: 425-432, 2003

37. Finch AR, Sedgley KR, Caunt CJ and McArdle AC: Plasma membrane expression of $\mathrm{GnRH}$ receptors: regulation by antagonist in breast, prostate, and gonadotrop cell lines. J Endocrinol 196: 353-367, 2008

38. Journot L, Spengler D, Pantaloni C, Dumuis A, Sebben M and Bockaert J: The PACAP receptor: generation by alternative splicing of functional diversity among $\mathrm{G}$ protein-coupled receptors in nerve cells. Semin Cell Biol 5: 263-272, 1994.

39. Ruppert S, Cole TJ, Boshart M, Schmid E and Schutz G: Multiple mRNA isoforms of the transcription activator protein CREB: generation by alternative splicing and specific expression in primary spermatocytes. EMBO J 11: 1503-1512, 1992.

40. Dal Toso R, Sommer B, Ewert M, Herb A, Pritchett DB, Bach A, Shivers BD and Seeburg PH: The dopamine D2 receptor: two molecular forms generated by alternative splicing. EMBO J 8: 4025-4034, 1989.

41. Sparks K, Mayer S and Dieckmann C: Premature 30 end formation of CBP1 mRNA results in downregulation of cytochrome $b$ mRNA during the induction of respiration in Saccharomyces cerevisiae. Mol Cell Biol 17: 4199-4207, 1997.

42. Eidne KA, Flanagan CA and Millar RP: Gonadotropin-releasing hormone binding sites in human breast carcinoma. Science 229 : 989-991, 1985.

43. Emons G, Ortmann O, Schulz KD and Schally AV: Growthinhibitory actions of analogues of luteinizing hormone releasing hormone on tumor cells. Trends Endocrinol Metab 8: 355-362, 1997.

44. Emons G, Müller V, Ortmann O and Schulz KD: Effects of LHRH-analogues on mitogenic signal transduction in cancer cells. J Steroid Biochem Mol Biol 65: 199-206, 1998. 
45. Emons G and Schally AV: The use of luteinizing hormone releasing hormone agonists and antagonists in gynaecological cancers. Hum Reprod 9: 1364-1379, 2000

46. Imai A, Horibe S, Takagi A and Tamaya T: Gi protein activation of gonadotropin-releasing hormone-mediated protein dephosphorylation in human endometrial carcinoma. Am J Obstet Gynecol 176: 371-376, 1997.

47. Limonta P, Moretti RM, Marelli MM, Dondi D, Parenti M and Motta M: The luteinizing hormone-releasing hormone receptor in human prostate cancer cells: messenger ribonucleic acid expression, molecular size, and signal transduction pathway. Endocrinology 140: 5250-5256, 1999

48. Limonta P, Montagnani Marelli M and Moretti RM: LHRH analogues as anticancer agents: pituitary and extrapituitary sites of action. Expert Opin Investig Drugs 10: 709-720, 2001.

49. Schally AV: LH-RH analogues: I. Their impact on reproductive medicine. Gynecol Endocrinol 13: 401-409, 1999.
50. Schally AV and Nagy A: Cancer chemotherapy based on targeting of cytotoxic peptide conjugates to their receptors on tumors. Eur J Endocrinol 141: 1-14, 1999.

51. Imai A and Tamaya T: GnRH receptor and apoptotic signaling. Vitam Horm 59: 1-33, 2000.

52. Gründker C, Schlotawa L, Viereck V and Emons G: Protein kinase $\mathrm{C}$-independent stimulation of activator protein-1 and c-Jun N-terminal kinase activity in human endometrial cancer cells by the LHRH agonist triptorelin. Eur J Endocrinol 145: 651-658, 2001

53. Moretti RM, Marelli MM, Dondi D, Poletti A, Martini L, Motta M and Limonta P: Luteinizing hormone-releasing hormone agonists interfere with the stimulatory actions of epidermal growth factor in human prostatic cancer cell lines, LNCaP and DU 145. J Clin Endocrinol Metab 81: 3930-3937, 1996. 